\title{
Effect of amino acids on pigments, citrinin, and lovastatin production by Monascus purpureus under static conditions
}

\author{
Padmavathi Tallapragada*, \\ Rashmi Dikshit, \\ Mudaheranwa Phocas, \\ Madhusudan. M.R.,

\section{Sanjana Samprathi} \\ Department of Microbiology, \\ Centre of PG Studies, Jain University, \\ 18/3, 9th Main, Jayanagar 3rd Block, \\ Bangalore, India
}

Monascus spp. is known to produce many secondary metabolites including pigments, statin, and undesired mycotoxin.

M. purpureus MTCC 410 strain was grown statically for ten days in potato dextrose broth supplemented with $1 \%$ UV sterilized amino acids. Whatmann filter No. 1 was used to separate the developed mycelia from the broth to get the intracellular pigment as the extracellular one is left in the filtrate. The pigment concentration was estimated by the calorimetric method for different wavelengths and expressed in colour value units (CVU). The presence of citrinin in the growth medium was checked under UV light at $350 \mathrm{~nm}$ and quantification was done with highperformance liquid chromatography column along with loop injector of $20 \mu \mathrm{l}$, and Shimadzu CLASS-VP version 5.032 software.

The maximum biomass (143.6 g/l) was observed with supplementation of $1 \% \mathrm{D}$-serine to the medium, whereas the maximum intracellular pigment yield was observed with supplementation of L-histidine monohydrochoride (yellow -4.48 , orange -3.97 and red pigment $-2.0 \mathrm{CVU} / \mathrm{ml}$ ). The maximum extracellular pigment yield was observed with supplementation of glycine (yellow - 2.18, orange -1.65 and red pigment $-1.38 \mathrm{CVU} / \mathrm{ml}$ to the growth medium). The maximum lovastatin yield was observed with supplementation of L-cysteine mono hydrochloride and concentration of $2064 \mathrm{mg} / \mathrm{l}$. Maximum citrinin (1.29 mg/l) was observed with supplementation of DL-norleucine to the growht medium.

$M$. purpureus requires suitable concentration of organic nitrogen in the form of amino acids for a higher yield of secondary metabolites such as supplementation of $1 \%$ L-cysteine monohydrochloride or L-tyrosine in the growth medium under submerged cultivation. None of the tested amino acids produced citrinin under experimental conditions making the outcome beneficial for industrial purposes.

Keywords: extracellular pigment, citrinin, amino acids, Monascus purpureus, biomass

\footnotetext{
* Corresponding author. E-mail: vam2010tpraviju@gmail.com, t.padmavathi@jainuniversity.ac.in
} 


\section{INTRODUCTION}

Monascus purpureus is a mould species, purplish-red in colour, in Ascomycota division, Monascaceae family. For a long time it has been traditionally important in China, Thailand, and Japan for production of red rice wine, red soybeans, cheese, and ang-kak rice. It was found capable of producing safe natural pigments along with other therapeutically important secondary metabolites, including citrinin and statins ( $\mathrm{Du}-$ fosse et al., 2005).

It contributes to consumers' favourite food colours, from orange-red to violet-red, by producing at least six major related pigments preferred over other synthetic pigments nowadays used in food industry, and are categorized into three main groups: yellow pigments (monascin and ankaflavin), orange pigments (rubropunctain and monascorubin), and red pigments (rubropunctamine and monoscorubramine) (Wang et al., 2007). They are synthesized as water insoluble, aminophiles and unstable in extreme $\mathrm{pH}$ in the cytosol from acetyl-coA through multi-enzymatic polyketide synthase complex (Balakrishnan et al., 2014) becoming water soluble after being in contact with present amino acids. Their aminophile characteristic makes them to be associated with cellular proteins or with the cell wall, and this makes them difficult to be extracted. Therefore their extraction requires cell breakage and dissolution in an organic solvent like methanol (Patricia et al., 2005; Liu et al., 2014).

However, as an undesired product, hepatonephrotoxin citrinin is known to be produced along with pigments and it limits the use of Monascus as a producer of natural food colourants (Jongrungruangchok et al., 2004). Its production is the main concern worldwide and it has to be prevented using any possible techniques like the use of mutagenic agents inducing mutation in a specific gene of an organism or inhibition of a specific responsible polyketide enzymes (PKSs) (Kang et al., 2014). Supplementation of specific amino acid and cultivation under controlled conditions can enhance the pigment production and inhibit citrinin production (Sameer et al., 2005; Liu et al., 2005).
Lovastatin works as another cholesterol-lowering agent by suppressing cholesterol synthesis via inhibition of HMG-CoA reductase enzyme, which mediates the biosynthesis of cholesterol in liver and is known as a potent inhibitor simvastatin (Ahmad et al., 2009). Thus the presence of lovastatin in bioproducts of an organism is an additional advantage making Monascus spp. important in medical and pharmaceutical industries by cooperatively working with other compounds or individually to stimulate body cells in the treatment of Alzheimer's disease or cancer, induction of apoptotic cell death, reduction of inflammation, inhibition of tumorigenesis and viral replication (Nicoleta et al., 2012).

The present study was conducted to screen amino acids for biomass, pigment, and citrinin and lovastatin production under static conditions.

\section{MATERIALS AND METHODS}

\section{Culture}

Monascus purpureus MTCC 410, obtained from IMTECH, Chandigarh India, was maintained on Potato Dextrose Agar (PDA) medium at $30^{\circ} \mathrm{C}$ for seven days and preserved at $4^{\circ} \mathrm{C}$, with subculturing once every four weeks; its purity was checked regularly (Dikshit, Tallapragada, 2013).

\section{Submerged fermentation}

Potato dextrose broth was sterilized by autoclaving, supplemented with UV sterilized $1 \%$ amino acids respectively, inoculated with a loopful of $M$. purpureus, and incubated for ten days under static conditions (Dikshit, Tallapragada, 2013).

\section{Biomass estimation}

After incubation, the mycelia was separated from the broth using Whatmann filter No. 1, obtained biomass was then weighed to determine the fresh biomass in grams per litre (Dikshit, Tallapragada, 2013).

\section{Pigment estimation}

Ten millilitres of both extracts were taken in two separate conical flasks and extra $10 \mathrm{ml}$ of methanol was added and incubated in the shaker 
incubatorfor 45 minutes, the filtrate was centrifuged at 10,000 rpm for 10 minutes. The pigment concentration was then determined by the colorimetric method where absorbance was measured at 450, 470, and $540 \mathrm{~nm}$ for yellow, orange, and red pigments respectively, and the colour value units were calculated. Colour value $=$ O.D. $\mathrm{x}$ dilution $\mathrm{x}$ volume of extract/amount of sample (ml) (Ratana, Toshima, 1987).

\section{Citrinin analysis}

The extract was transferred into vials and saturated until the volume reduced to half of the original, 10 microliters of it was applied to Silica gel 60 F254 Aluminium sheets (Merck, Germany) using Ethyl acetate: acetone: water $(4: 4: 1 \mathrm{v} / \mathrm{v})$ as the mobile phase, and dried plates were examined under UV light at $350 \mathrm{~nm}$ to observe fluorescent yellow bands indicating the presence of citrinin. For its confirmation, High Performance Liquid Chromatography (HPLC) analysis was carried out, column with C18 with $250 \times 4.6 \mathrm{~mm}$ width ID Lichrosper 100 and $5 \mu \mathrm{m}$ particle size, along with loop injector of $20 \mu \mathrm{l}$, and Shimadzu CLASS-VP version 5.032 software, with a mobile phase made of Acetonitrile/water $(65: 35 \mathrm{v} / \mathrm{v}$ and $3.5 \mathrm{pH})$ acidified with ortho-phosphoric acid (Panda et al., 2010). Citrinin concentration was then estimated using the formula: Area of the sample/Area of the std $\times$ Amount of std/Dilution of std $\times$ Dilution of sample/amount of sample.

\section{Estimation of lovastatin}

Stock solution of lovastatin $(6 \mathrm{mg} / \mathrm{ml})$ was prepared in ethanol using pure and standard lovastatin gifted by Biocon, Bangalore, India. Hydroxylamine hydrochloride (12.5\%) and sodium hydroxide (12.5\%) both in methanol were prepared by refluxing $12.5 \mathrm{~g}$ of the solid material with $100 \mathrm{ml}$ of methanol for few minutes, then their equal volumes were mixed and the precipitated sodium chloride was filtered off to obtain alkaline hydroxylamine reagent being used in 4 hours.

Ferric perchlorate (stock solution) was prepared by adding $0.8 \mathrm{~g}$ of iron powder into a $50 \mathrm{ml}$ beaker, then in a closed fuming hood,
$10 \mathrm{ml}$ of $70 \%$ perchloric acid was added and heated until the iron dissolved. As iron dissolves very rapidly when the acid is hot, the reaction may become vigorous and the content was cooled in the fuming hood. Then $40 \mathrm{ml}$ of this stock was mixed with $12 \mathrm{ml}$ of $70 \%$ perchloric acid and the volume was made up to $100 \mathrm{ml}$ with ethanol to make Ferric perchlorate reagent (Mohie et al., 2010).

Lovastatin was estimated by different aliquots of standard lovastatin $(6 \mathrm{mg} / \mathrm{ml})$ ranging from $20 \mu \mathrm{l}$ to $100 \mu \mathrm{l}$ transferred into a series of test tubes: $1 \mathrm{ml}$ of alkaline hydroxylamine reagent was added to each test tube, then $\mathrm{pH}$ was adjusted to $1.2 \pm 0.2$ by adding an appropriate volume of $2 \mathrm{M} \mathrm{HCl}$, followed by addition of $2 \mathrm{ml}$ of ferric perchlorate reagent. After 25 minutes of incubation at room temperature, the absorbance values of the red colour product formed were read at $510 \mathrm{~nm}$ (Mohie et al., 2010). The same procedure was followed for the test samples.

\section{RESULTS AND DISCUSSION}

\section{Identification of Monascus purpureus MTCC 410}

The morphological characteristics of Monascus purpureus were identified by the pattern of its growing on potato dextrose agar. The mycelium was white in the early stages; however, it rapidly changed to rich pink and subsequently to distinctive yellow-orange colour (Fig. 1a, b). Deep crimson colour was formed as the culture aged (Patcharee et al., 2007).

\section{Effect of amino acids on biomass production}

Among all 24 different amino acids tested for biomass production, the results showed that M. purpureus produced maximum fresh biomass of $143.66 \mathrm{~g} / \mathrm{l}$ with supplementation of $1 \%$ D-serine (Table 1). Amino acids promoted biomass production.

The growth and sporulation pattern of filamentous fungi are showing variable nature with supplementation of different amino acids and nitrogen sources. Growth and biomass production will also vary with the organisms used and provided growing factors, including 


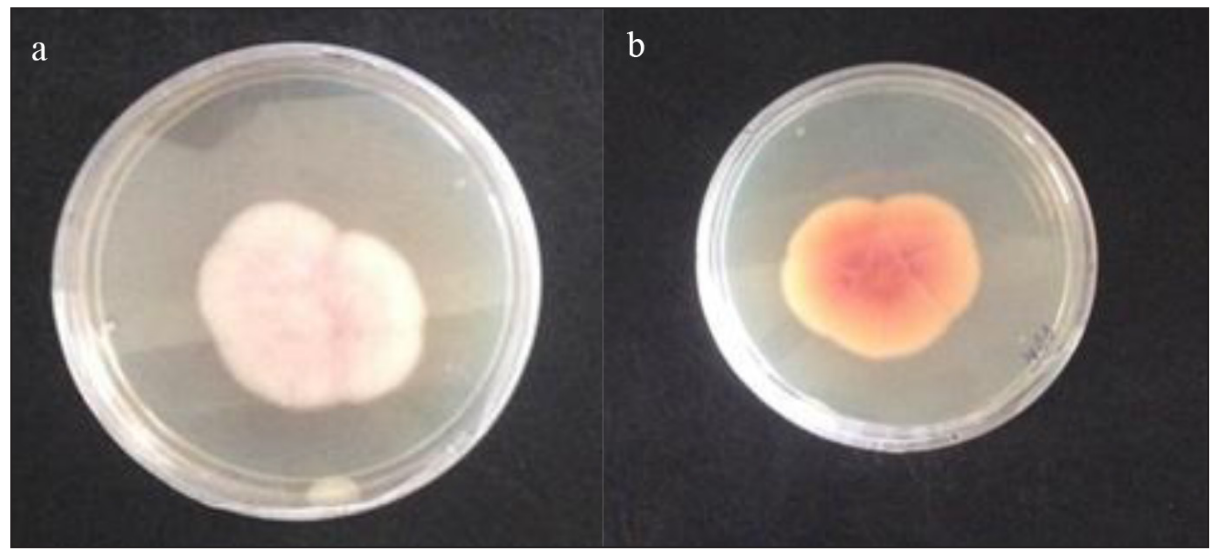

Fig. 1a. Dorsal view of M. purpureus 1b: Ventral view of M. purpureus

Table 1. Screening of amino acids for biomass and pigment production under static conditions

\begin{tabular}{|c|c|c|c|c|c|c|c|c|}
\hline \multirow{2}{*}{$\begin{array}{l}\text { Sl. } \\
\text { No. }\end{array}$} & \multirow{2}{*}{ Amino acid } & \multirow{2}{*}{$\begin{array}{l}\text { Fresh bio- } \\
\text { mass }(g / L)\end{array}$} & \multicolumn{3}{|c|}{ Intracellular (cvu/ml) } & \multicolumn{3}{|c|}{ Extracellular (cvu/ml) } \\
\hline & & & yellow & orange & red & yellow & orange & red \\
\hline 1. & DL-alanine & 2.6 & 0.25 & 0.12 & 0.24 & 0.20 & 0.08 & 0.19 \\
\hline 2. & DL-2-amino-n butyric acid & 43.3 & 0.84 & 0.70 & 0.77 & 0.23 & 0.09 & 0.15 \\
\hline 3. & L-a mono-hydrochloride & 66.6 & 0.32 & 0.19 & 0.27 & 0.36 & 0.22 & 0.17 \\
\hline 4. & DL-aspartic acid & 30 & 0.31 & 0.17 & 0.18 & 0.07 & 0.14 & 0.05 \\
\hline 5. & $\begin{array}{c}\text { L-cysteine mono-hydrochlo- } \\
\text { ride }\end{array}$ & 33.3 & 0.09 & 0.04 & 0.03 & 0.07 & 0.16 & 0.04 \\
\hline 6. & L-cysteine & 66.6 & 3.04 & 2.58 & 2.26 & 0.73 & 0.61 & 0.43 \\
\hline 7. & $\begin{array}{l}\text { 3-(3,4-dihydroxy phenyl) DL- } \\
\text { alanine }\end{array}$ & - & - & - & - & - & - & - \\
\hline 8. & L-glutamic acid & 120 & 2.37 & 1.86 & 2.0 & 0.57 & 0.46 & 0.34 \\
\hline 9. & Glycine & 136.6 & 1.02 & 0.89 & 0.61 & 2.18 & 1.65 & 1.38 \\
\hline 10. & $\begin{array}{c}\text { L-histidine mono hydrochlo- } \\
\text { ride }\end{array}$ & 136.6 & 4.48 & 3.97 & 2.0 & 0.68 & 1.21 & 0.3 \\
\hline 11. & L-hydroxyl proline & 60 & 2.24 & 1.81 & 1.92 & 0.35 & 0.21 & 0.14 \\
\hline 12. & L-leucine & 90 & 0.9 & 0.8 & 0.61 & 0.63 & 0.53 & 0.38 \\
\hline 13. & L-isoleucine & 120 & 0.34 & 0.23 & 0.28 & 0.56 & 0.46 & 0.36 \\
\hline 14. & DL-norleucine & 70 & 0.57 & 0.46 & 0.44 & 0.62 & 0.51 & 0.38 \\
\hline 15. & L-lysine mono hydrochloride & 66.6 & 1.92 & 1.44 & 1.68 & 0.26 & 0.12 & 0.10 \\
\hline 16. & L-methionine & 113.3 & 1.78 & 1.33 & 1.49 & 0.24 & 0.11 & 0.16 \\
\hline 17. & $\begin{array}{l}\text { DL-ornithine mono hydro- } \\
\text { chloride }\end{array}$ & 77.6 & 1.10 & 1.00 & 0.82 & 0.84 & 0.73 & 0.59 \\
\hline 18. & L-proline & 8.3 & 0.1 & 0.02 & 0.12 & 0.34 & 0.22 & 0.28 \\
\hline 19. & DL- $\beta$-phenyl alanine & 128.3 & 0.84 & 0.74 & 0.7 & 1.00 & 0.92 & 0.72 \\
\hline 20. & D-serine & 143.6 & 3.22 & 2.8 & 3.41 & 0.14 & 0.01 & 0.10 \\
\hline 21. & L-tyrosine & 8 & 0.32 & 0.08 & 0.34 & 0.68 & 0.44 & 0.58 \\
\hline 22. & DL-valine & 28 & 0.16 & 0.18 & 0.20 & 0.32 & 0.08 & 0.30 \\
\hline 23. & DL-threonine & 24 & 0.32 & 0.04 & 0.38 & 1.44 & 1.14 & 1.34 \\
\hline 24. & DL-tryptophan & 30 & 1.2 & 0.74 & 0.84 & 2.06 & 1.50 & 0.68 \\
\hline
\end{tabular}


the conditions like static fermentation condition. On the other hand, the nitrogen source plays a major role in enhancing sporulation, so that the spore germination results in increased mycelia (biomass). Amino acids have been essential nutrients; they participated in the metabolic transformations during spore germination leading from polar to non-polar phases of growth (Rajendra, 2006).

\section{Effect of amino acids on pigment production} Supplementation of 1\% L-histidine monohydrochloride yielded maximum yellow, orange, and red intracellular pigments of 4.48, 3.97 and $2.0 \mathrm{CVU} / \mathrm{ml}$, respectively, and $1 \%$ glycine yielded maximum yellow, orange and red extracellular pigments of $2.18,1.65$ and $1.38 \mathrm{CVU} / \mathrm{ml}$, respectively.

As the Monascus culture ages, the pigments are extracellular, safe, nontoxic, and with high stability against $\mathrm{pH}$, light, and temperature (Patcharee, 2007). Submerged fermentation medium with amino acids promotes better production of extracellular red pigments, most of them being a complex of pigments and amino acids (Blanc et al., 1994). Histidine monohydrochloride mainly increased the intracellular red pigment, while the extracellular one was kept very low, almost equal to that of the control. Presumably, the amino acid might have en- tered the Monascus cell where the nitrogen in its amino group might have replaced the oxygen of the orange pigment resulting in the red pigment, so, the intracellular red pigment was higher than extracellular.

Glycine resulted in a large quantity of extracellular pigments. Very likely it changed the permeability of the membrane allowing the intracellular orange pigment to be secreted out of the cell and to react with corresponding amino acid in medium resulting in red pigments.

Conversely, supplementation of 3-(3, 4-dihydroxy phenyl)-DL-alanine completely inhibited pigment production. Similarly, L-cysteine monohydrochloride mainly reduced the intracellular but not extracellular pigment production. The results revealed a close relationship between the supplementation of amino acids and the production and secretion of the pigment. This was significantly meaningful for changing the components of the pigment and increasing the intracellular and extracellular pigment production (Xiao et al., 2013).

\section{Citrinin analysis of Monascus purpureus by TLC and HPLC}

The presence of citrinin was identified by means of TLC (Fig. 2) and further confirmed by HPLC; its production was found completely

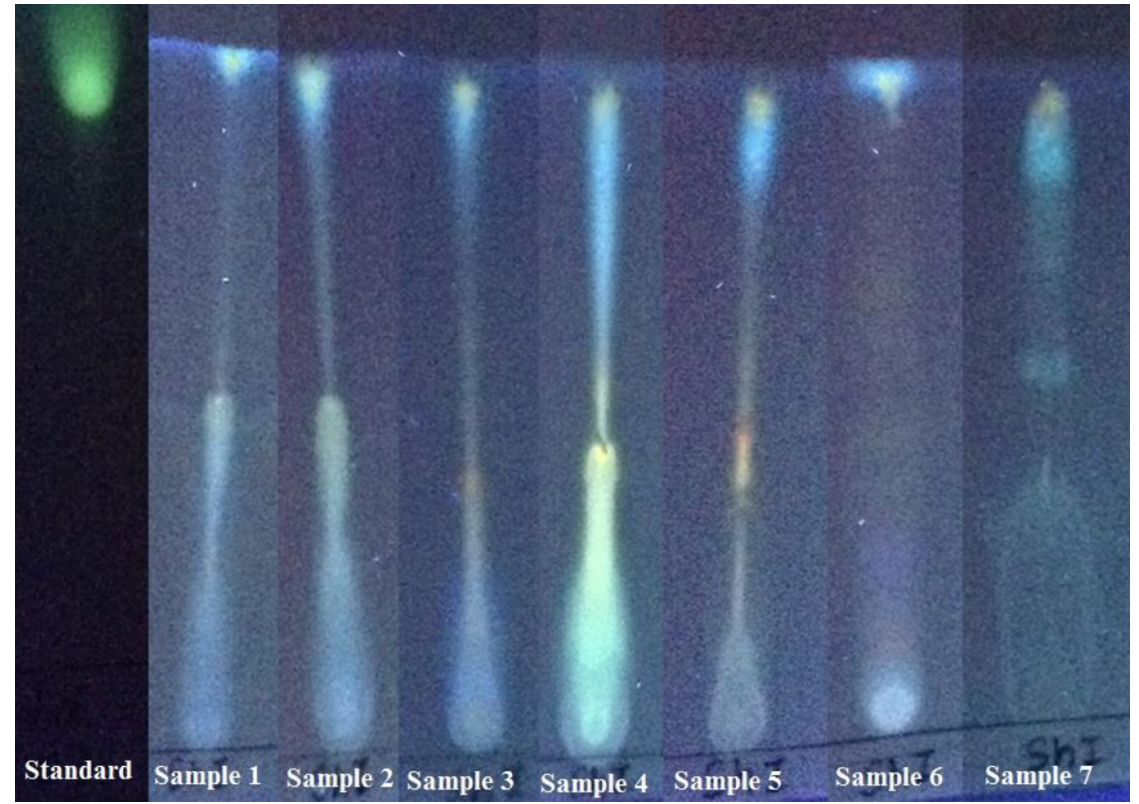

Fig. 2. Citrinin determination by TLC 
inhibited under static conditions. Hajjaj et al. (2012) suggest that the precursor for both pigments and citrinin is tetraketide formed by condensation of one acetyl-CoA molecule and three malonyl-CoA molecules.

To obtain $M$. purpureus bio-products with low or zero citrinin, 24 different amino acids were screened under static condition and only few amino acid-supplemented medium was able to produce citrinin. Maximum citrinin $(1.29 \mathrm{mg} / \mathrm{l})$ was observed with supplementation of DL-norleucine (Table 2).

This might have inhibited the production of citrinin. Citrinin production also showed dependency on static and shaking culture conditions. Under static conditions a significantly lesser quantity of citrinin was produced. Hence, supplementation of appropriate amino acids under static conditions can be recommended for the production of larger quantities of the pigment and lovastatin and for a lower concentration of citrinin.

\section{Production and quantification of lovastatin}

Production and quantification of lovastatin was observed by the colorimetric method (Mohie et al., 2010) where estimation was performed using pure standard lovastatin. The lactone ring of these drugs reacts with hydroxylamine in alkaline medium to form the corresponding hydroxamic acid derivatives which, treated with ferric ions in acid medium, yield highly coloured ferric chelate complex read at $510 \mathrm{~nm}$. Among 24 different amino acids tested, 3-(3,4-dihydroxy phenyl) DL-alanine and L-isoleucine did not produce lovastatin, L-cysteine monohydrochloride produced maximum extracellular lovastatin $(2064 \mathrm{mg} / \mathrm{L})$ and obtained the concentration of lovastatin compatible to the one reported by Nirogi et al. (2007). The amount of intracellular and extracellular lovastatin produced statically was higher than the one produced under shaking conditions, and the observations revealed a possible reason for this increase: it is possible that the rotational speed fragments the mycelium of $M$. purpureus thereby reducing the lovastatin production. Under static conditions, the culture was undisturbed thus enhancing the production of lovastatin. Conversely, 1\% L-cysteine monohydrochloride-supplemented medium biomass was comparatively low, so our results revealed that the biomass production had no relation with lovastatin production. However, production depends on the organic nitrogen source such as L-cysteine monohydrochloride in the medium. Our results were in agreement with Tsuyoshi et al. (2006).

The glucose present in the medium strongly repressed lovastatin production. The appropriate release is achieved by optimizing the medium composition to produce high amount of lovastatin. This production is via polyketide pathway, which is responsible for synthesizing many secondary metabolites with complex chemical structures. The genes and enzymes involved have been identified and characterized (Kennedy et al., 1999). It is becoming apparent that both carbon and nitrogen sources regulate lovastatin biosynthesis at the level of glucose repression.

Table 2. Citrinin concentration produced by Monascus purpureus MTCC 410

\begin{tabular}{cccccc}
\hline Sl. No. & Amino acid & Retention time (min) & Area (mV.s) & Concentration (mg/L) \\
\hline 1. & Standard & 2.043 & 81.103 & \\
\hline 2. & DL-alanine & 2.113 & 3.746 & 0.92 \\
\hline 3. & L-cysteine & 2.067 & 0.784 & 0.19 \\
\hline 4. & DL-norleucine & 2.113 & 5.257 & $\mathbf{1 . 2 9}$ \\
\hline 5. & L-proline & 2.057 & 3.679 & 0.90 \\
\hline 6. & D-serine & 2.020 & 0.670 & 0.16 \\
\hline
\end{tabular}


Table 3. Estimation of lovastatin produced intracellularly and extracellularly by Monascus purpureus under static conditions

\begin{tabular}{|c|c|c|c|}
\hline \multirow[t]{2}{*}{ Sl. No. } & \multirow[t]{2}{*}{ Amino acid } & \multicolumn{2}{|c|}{$\begin{array}{l}\text { Amount of lovastatin produced (concentration in } \\
\qquad \mathrm{mg} / \mathrm{L} \text { ) }\end{array}$} \\
\hline & & Intracellular & Extracellular \\
\hline 1. & DL-alanine & 24 & 960 \\
\hline 2. & DL-2-amino-n butyric acid & 96 & 78 \\
\hline 3. & L-arginine mono-hydrochloride & 120 & - \\
\hline 4. & DL-aspartic acid & 174 & 792 \\
\hline 5. & L-cysteine mono hydrochloride & - & 2064 \\
\hline 6. & L-cysteine & - & 96 \\
\hline 7. & 3-(3,4-dihydroxy phenyl) DL-alanine & - & - \\
\hline 8. & L-glutamic acid & 174 & 288 \\
\hline 9. & Glycine & 288 & 156 \\
\hline 10. & L-histidine mono-hydrochloride & 330 & 270 \\
\hline 11. & L-hydroxyl proline & 210 & 306 \\
\hline 12. & L-leucine & - & - \\
\hline 13. & L-isoleucine & 138 & 138 \\
\hline 14. & DL-norleucine & 288 & 192 \\
\hline 15. & L-lysine mono hydrochloride & 24 & 60 \\
\hline 16. & L-methionine & 24 & 24 \\
\hline 17. & DL-ornithine mono hydrochloride & 210 & 234 \\
\hline 18. & L-proline & 156 & 768 \\
\hline 19. & DL- $\beta$-phenyl alanine & 252 & 192 \\
\hline 20. & D-serine & 252 & 192 \\
\hline 21. & L-tyrosine & 210 & 1944 \\
\hline 22. & DL-valine & 234 & 1392 \\
\hline 23. & DL-threonine & 156 & 1128 \\
\hline 24. & DL-tryptophan & 96 & 960 \\
\hline
\end{tabular}

\section{CONCLUSIONS}

The study revealed that specific amino acids at $1 \%$ influence the type and amount of extracellular or intracellular bio-products and fresh biomass produced $M$. purpureus under submerged static conditions. As it is produced by industrially important pigments, $M$. purpureus can be manageable in the way of setting adequate conditions to produce the desired pure products (pigments, lovastatin, biomass) in large amounts and to inhibit undesired ones like citrinin. At $1 \%$, D-serine must be used as nitrogen source to produce large amounts of fresh biomass under static conditions. For the purpose of pigments, either L-histidine monohydrochloride or glycine can be used to produce a large amount intra- or extracellularly, respectively. This is a new tool for substitution or replacement of industrial detrimental synthetic pigments. Now Monascus citrinin is no longer a problem as amino acids like L-histidine monohydrochloride and glycine, which are pigment enhancers under static condition, completely inhibit the citrinin production. M. purpureus requires a suitable concentration of organic nitrogen in the form of amino acids for high lovastatin production, therefore supplementation of $1 \%$ L-cysteine monohydrochloride 
or L-tyrosine to the potato dextrose medium with submerged cultivation is beneficial in seeking maximum amount of lovastatin production. Supplementation of amino acids under static conditions is a novel methodology to enhance biomass, pigments, lovastatin production, and to reduce citrinin production, and can be adapted by industries for maximum production of pigments and lovastatin by Monascus spp.

Received 28 February 2017

Accepted 5 June 2017

\section{References}

1. Ahmad A, Panda BP, Khan S, Ali M, Javed S. Downstreaming and purification of lovastatin from Monascus purpureus culture. Thai J Pharm Sci. 2009; 33: 39-46.

2. Balakrishnan B, Kim HJ, Suh JW, Chen CC, Liu KH, Park SH, Kwon HJ. Monascus azaphilone pigment biosynthesis employs a dedicated fatty acid synthase for short chain fatty acyl moieties. J Korean Soc Appl Bi. 2014b; 57(2): 191-6.

3. Blanc PJ, Loret MO, Santerre AL, Pareilleux A, Prome D, Prome JC. Pigments of Monascus. J Food Sci. 1994; 59: 862-5.

4. Dikshit R, Tallapragada P. Comparative Study of Monascus sanguineus and Monascus purpureus for red pigment production under stress conditions. Int Food Res J. 2013; 20(3): 1235-8.

5. Dufosse L, Galaup P, Yaron A, Arad SM, Blanc P, Chidambara MKN, Ravishankar GA. Microorganisms and microalgae as sources of pigments for food use: a scientific oddity or an industrial reality? Trends Food Sci Tech. 2005; 16(9): 389-406.

6. Hajjaj H, François J-M, Goma G, Blanc PJ. Effect of amino acids on red pigments and citrinin production in Monascus ruber. J Food Sci. 2012; 77(3): 156-9.

7. Jongrungruangchok S, Kittakoop P, Yongsmith B, et al. Azaphilone pigments from a yel- low mutant of the fungus Monascus kaoliang. Phytochemistry. 2004; 65(18): 2569-75.

8. Kang B, Zhang X, Wu Z, Wang Z, Park S. Production of citrinin-free Monascus pigments by submerged culture at low pH. Enzyme Microb Technol. 2014; 55: 50-7.

9. Kennedy J, Auclair K, Kendrew SG, Park C, Vederas JC, Hutchinson CR. Modulation of polyketide synthase activity by accessory proteins during lovastatin biosynthesis. Science. 1999; 284: 1368-72.

10. Liu BH, WTS, Su MC, Chung CP, Yu JFY. Citrinin Induces Apoptosis in Mouse Embryonic Stem Cells. Agric Food Chem. 2005; 53: $170-5$.

11. Liu Q, Xie N, He Y, Wang L, Shao Y, Zhao H, Chen F. Mpig E. A gene involved in pigment biosynthesis in Monascus ruber M7. Appl Microbiol Biotechnol. 2014; 98(1): 285-96.

12. Mohie MK, Sharaf El-D, Khalid AM, Attia M, Nassar WI, Mohamed MYK. Colorimetric determination of simvastatin and lovastatin in pure form and in pharmaceutical formulations. Spectrochim Acta A. 2010; 423-8.

13. Nicoleta R, Sanda MD, Mariana F, Aurora S, Ileana R. Biostimulatory Properties of Monascus sp. Bioproducts, Mol Cryst Liq Cryst. 2012; 555(1): 195-201.

14. Nirogi R, Madigonda K, Kandikere V. Liquid chromatography/negative ion electro spray tandem mass spectrometry method for the quantification of fluvastatin in human plasma; validation and its application to pharmaco kinetic studies. J Pharm Biomed. 2007; 44: 379 .

15. Panda BP, Saleem J, Mohd A. Production of Angkak through Co- culture of Monascus purpureus and Monascus ruber. Braz J Microbiol. 2010; 41: 757-64.

16. Patcharee P, Renu P, Aphirak P, Noppol E. Review of Angkak production by (Monascus purpureus), Chiang Mai J Sci. 2007; 34(3): 319-28.

17. Patricia SH, Sandra FBO, Beatriz VK. Concentration determination of extracellular 
and intracellular red pigments produced by Monascus sp. Braz Arch Biol Technol. 2005; 48: 43-9.

18. Rajendra KG. The effect of amino acids on growth and sporulation of Aspergillus flaws and their carry-over for subsequent spore germination. New Phyto. Version of record online May 2006; 63(1): 1-10.

19. Ratana S, Toshima Y. Solid state fermentation for yellow pigments production by Monascus purpureus. World J Microbiol Biotechnol. 1987; (6): 347-52.

20. Sameer AS, Mapari KNF, Thomas LO, Jens FC, Ulf T, Anne SM. Exploring fungal biodiversity for the production of water-soluble pigments as potential natural food colorants. Curr Opin Biotechnol. 2005; (16): 231-8.

21. Tsuyoshi M, Kumiko U, Ming YZ, Isato K, Nobuyuki N, Hiroyuki S, Kenji I. Effects of the principal Nutrients on lovastatin production by Monascus pilosus. Biosci Biotechnol Biochem. 2006; 70(5): 1154-59.

22. Wang TH, Lin TF. Monascus rice products. Adv Food and Nutr Res. 2007; (53): 123-59.

23. Xiao-Wei Z, Jia-Hua W, Mian-Hua C, ChangLu W. Effect of Nitrogen Sources on Production and Photostability of Monascus Pigments in Liquid Fermentation. IERI Procedia. 2013; (5): 344-50.
Padmavathi Tallapragada, Rashmi Dikshit, Mudaheranwa Phocas, Madhusudan. M. R., Sanjana Samprathi

\section{AMINORŪGŠČIŲ POVEIKIS PIGMENTŲ, CITRININO IR LOVASTATINO GAMYBAI IŠ MONASCUS PURPUREUS STATINĖMIS SĄLY- GOMIS}

\section{Santrauka}

Monascus rūšys gamina daug antrinių metabolitų, iskaitant pigmentus, statinus ir nepageidaujamus mikotoksinus. Monascus purpureus yra rausvai raudonos spalvos pelèsių rūšis, pajègi gaminti saugius natūralius pigmentus ir kitus svarbius antrinius metabolitus, įskaitant citrininą ir statinus. Šio tyrimo metu M. purpureus MTCC 410 padermé 10 dienų buvo statiškai auginta bulvių dekstrozès terpèje su $1 \%$ UV sterilizuotų aminorūgščių. Gauto pigmento koncentracija ívertinta kolorimetriniu metodu, esant skirtingam bangos ilgiui, ir išreikšta spalvinès vertès vienetu (CVU). Citrininas nustatytas UV šviesoje (bangos ilgis $350 \mathrm{~nm}$ ) ir kiekybiškai ịvertintas su skysčių chromatografija. Didžiausia biomasè $(143,6 \mathrm{~g} / \mathrm{l})$ nustatyta terpèje su $1 \% \mathrm{D}$-serino papildu, o didžiausia viduląstelinio pigmento išeiga gauta terpejje su L-histidino monohidrochloridu (4,48 geltono, 3,97 oranžinio ir 2,0 CVU/ml raudono pigmento). Didžiausia ekstraląstelinio pigmento išeiga gauta terpeje su glicinu (2,18 geltono, 1,65 oranžinio ir 1,38 CVU/ml raudono pigmento), didžiausia lovastatino išeiga (2 $064 \mathrm{mg} / \mathrm{l}$ ) gauta terpejje su L-cisteino monohidrochloridu, o citrinino (1,29 mg/l) - terpeje su DL norleucinu.

Raktažodžiai: ekstraląstelinis pigmentas, citrininas, aminorūgštys, Monascus purpureus, biomasè 